\title{
Senior entrepreneurship - key facts at regional level in Romania
}

\author{
Laura BLID \\ The Bucharest University of Economic Studies, Doctoral School for Business Administration, \\ Bucharest, Romania \\ laura.blid@fabiz.ase.ro
}

\begin{abstract}
Senior population is still a valuable resource for the labour market and for entrepreneurship. While ageing population is a global phenomenon and solution are needed to milder the economic impact, there are also to consider the positive outcomes related to the optimal use of potential in the senior population and the benefits of an active life upon the elderly. This paper focuses on the entrepreneurial activity of senior population at regional level in Romania (Bucharest-Ilfov and South-Muntenia), considering a panel of 200 limited liability companies established in the last 5 years, by a single shareholder aged 60+ years. The empirical descriptive study is mainly based on the information about these companies searched for on the Ministry of Finance website. The paper aims to answer questions related to entrepreneurial activity of grey population like e.g. fields of activity raising interest of senior entrepreneurs at regional level in Romania and size of companies in terms of employees' number and yearly turnover. The paper presents few considerations in view of assessing some dimensions of this phenomenon of senior entrepreneurship at regional level in Romania, based on the data obtained for the last 5 years. The results of this analysis will be enhanced by a further study on the same panel addressing mainly motivational drivers to start-up a business.
\end{abstract}

Keywords: senior entrepreneurship, older entrepreneur, grey entrepreneur, active ageing, Romania.

\section{Introduction}

According to United Nations, Europe is the oldest continent and has the highest old age dependency ratio. But ageing population is - with the exception of Africa - a common issue to all continents. Ageing population is an issue of big concern because of its effects on the public resources. European Commission reports indicate even a worsening trend for EU-28 as the dependency ratio is projected to almost double by 2080 .

Population ageing impacts significantly public spending especially through higher pensions amounts and medical care expenditures. The policy makers are urged to find solutions to milder the consequences of the ageing population process. Main steps were pension reform and preoccupation for reducing age discrimination. But these approaches are not exhaustive. There have to be found further alternatives. Entrepreneurship may be one possibility to retain older people in the working field (Kautonen, 2008).

The interest to milder the consequences of ageing population process continued to grow in importance at global level over last decades. Thus the subject of ageing population made the core of many articles, statistics, researches. The topic was studied in detail and implications and correlations to many other aspects were considered. There have been approached topics like active ageing, healthy ageing, physical activity for elderly, etc. All these concepts are interrelated and the cumulative advantages of these might have positive effects able to counteract to a certain degree the negative impact of an ageing population. Senior entrepreneurship could also have its contribution. For Romania the information 
available on senior entrepreneurship is really limited. This paper aims to partially fill in this gap. The paper reveals aspects related to the entrepreneurial activity of people aged 60 and above at regional level in Romania.

\section{Literature review}

\section{Active ageing - a central concept}

PICBE $\mid 140$

According to European Commission life expectancy is increasing, however the percentage of years affected by health related issues in total life of an individual is $20 \%$ in average. That is why preserving health for a longer period is extremely important.

The European Innovation Partnership (EIP) on Active and Healthy Ageing (AHA) makes - as the name it saying- out of better health and active ageing of Europeans its main priorities (European Commission). According to WHO (2002) active ageing is meant to optimize chances for better health, participation and security. Moulaert and Paris (2013) noticed differences between active ageing policy of EU and of WHO. EU's policy in this field aims to achieve the highest possible inclusion of older people in social and economic life (Lassen and Moreira, 2014). Active ageing terminology has been refined by referring to concerted strategies for ensuring best participation at all levels (including cultural level) during entire life span (Kalache and Kickbush, 1997, Walker 2009). Lassen and Moreira (2014) consider active ageing as a plural reality.

Bierwisch et al. (2014) argued that active ageing and demographic issues should be given more significance and be considered from early stages of projects beside technical related aspects. Aisa et al. (2015) concluded that a lower dependency ratio could be ensured by a health sector designed to provide very good health services, thus supporting individuals to stay healthy and active for a longer time.

Regular physical activity has proved to offer considerable physical, mental and social benefits, also in later years. A strategy aiming to stimulate physical activity at older ages could start with prosocial behavior (Foy et al., 2013). The consciousness also has to change. A positive image upon later stages of life will help older adults to act in the sense of preserving health (Levy and Myers, 2004; Emile et al., 2014). Kean et al. (1993) found that older entrepreneurs show higher autonomy, independence and personal effectiveness. They also pointed out two characteristics specific rather only to the grey entrepreneurs' category meaning a better level of personal fitness and of family support. As a conclusion, starting a new business seems to have as basic requirement a good health of the initiator (Botham and Graves, 2009). That is why, as already mentioned, healthy and active ageing, longevity, some economic aspects related to ageing population are interrelated and influence each other and should be considered as such by the policy makers.

\section{Older entrepreneurs, motivational drivers and external factors with positive influence on start-up decision}

One of the goals of 2012 European Year of Active Ageing and Solidarity between Generations (OECD/European Union, 2012) was to promote senior entrepreneurship. The development of the entrepreneurship within ageing population and the factors stimulating this phenomenon make a great research subject, being useful, relevant, insufficiently researched especially for Romania. 
In 2014 Kraus and Bouncken offered a summary of the concepts referring to older entrepreneurs and entrepreneurship in ageing population. That valuable list can be enhanced by other concepts like later-life entrepreneurs (Rogoff, 2008), elderly entrepreneurs (Zhang, 2008). Olderpreneurs, seniorpreneurs or silverpreneurs are also concepts in the same context, though e.g. seniorpreneur was initially used by Arkebauer (1995) to address individuals over age of fifty having a small business, not only those founding a company after this age.

No general consensus has been reached for defining "ageing" or "older"; Weber and Scharper (2004) proposed the segregation limit to be the retirement age, meaning 65 in several countries. 62 is the right age for others (Zhang, 2008), while many scholars consider that ageing entrepreneurs are the 50 years+ individuals launching into start-ups or selfemployment (Baucus and Human, 1994, Kautonen 2008, Ainsworth 2015). Weber and Schaper (2004) helped by offering flexibility to definition of "grey entrepreneur" proposing to be an individual over a certain age who starts a business. For the purpose of this paper the right age threshold was 60 years.

It has been argued that age and age related specifics are key factors impacting upon entrepreneurship and self-employment (Parker, 2009). Scholars asserted that both desire and probability of seniors to start businesses have a downward trend as the age increases (Blanchflower et al., 2001, Curran and Blackburn, 2001). Studying entrepreneurs of all ages, it has been found that the impact of age upon the likeliness to engage in entrepreneurial activity would describe an inverse U-shape (Lévesque and Minniti, 2006, Bergmann and Sternberg, 2007). However Kautonen et al. (2014) argued that the effect of age resembles an inverse U-shape only for the owner-managers, not for self-employers or reluctant entrepreneurs. Bohlman et al. (2017) enhanced the inverse U-shape theory by arguing that also the relationship between age and both perceived opportunities and perceived skills were weakly curvilinear (i.e. inversely U-shaped). A weaker health could be the explanation for the decrease in perceived skills of the ageing population. On the other hand, the experience can balance some decline regarding mental agility and cognition (Staudinger, 1999). Nevertheless physical abilities also play an important role. Botham and Graves, 2009 considered health condition as significant impediment among individuals choosing not to start-up a business. In contrast with previous studies explaining the inverted U-shape between age and probability to launch a business, Thorgren et al. (2016) found that secondstep entrepreneurial choice (leave wage employment to become a full-time entrepreneur) shows a U-shape connection between age and intention to start entrepreneurial activities.

There are many articles on the motivational drivers to become entrepreneur. The literature identified 'pull' and 'push' factors (Buttner and Moore, 1997; Kautonen, 2008) based on market opportunities and unfavorable circumstances perceived by the entrepreneurs, which lead to necessity-driven and opportunity-driven entrepreneurship. The 'pull' factors are considered positive factors like independence, autonomy (Adrien et al., 1999), desire to increase income and social inclusion, implement own ideas (Kautonen et al., 2008), pursuing self-fulfilment, turning hobbies into profession or striving for personal success, social promotion and a high living standard (Maâlaoui et al., 2013), factors related in general to choices of entrepreneurs and desire of seizing opportunities. On the other side, 'push' factors are rather external, negative factors forcing toward 
entrepreneurship. These may be unsecure job or dissatisfaction with the current job, redundancy, not finding a job, the need to better harmonize work and family, insufficient retirement funds etc. (Singh and DeNoble, 2003, Walker and Webster, 2007, Weber and Schaper, 2004). Giacomin et al. (2007) consider that decision to enter entrepreneurship may be based at the same time on both types of factors (push and pull). Kautonen (2008) concluded in a study on Finnish market that a small percentage of senior entrepreneurs (about 10\%) were necessity-driven. Robichaud et al. (2010) found on a study based on GEM data for Canada from 2002 to 2004 that opportunity-driven entrepreneurs were predominant. However Harms et al. (2014) identified in their study on Rhine Valley several reasons determining older entrepreneurs to start businesses, with similar weights of pull and push-type factors. The authors also argued the valuable contribution of some older entrepreneurs through their businesses, having aspirations and remaining open to technological developments. Opportunity entrepreneurship was found to be associated with more growth-oriented businesses (Fairlie and Fossen, 2017, Verheul and van Stel, 2007).

When the studied population -as in case of Romania - mainly displays a negative attitude towards entrepreneurship and the intention to start a business in the age group 60+ is declining (Păunescu and Blid, 2017), in order to identify most appropriate economic and political measures to encourage entrepreneurship in older ages it is important to study this phenomenon, to understand key details like who is the senior entrepreneur, why does he/she choose to become an entrepreneur, which are the main external factors with a positive influence on entrepreneurial choice in later years. There are various drivers increasing the desire of grey population to start a business or to become self-employed, and there is room for further researches in this field (Păunescu and Blid, 2017). The factors are stretching out from the level of each individual (own situation in terms of resources, experience, family situation and personal network) to regional factors and beyond to macroeconomic factors. Curran and Blackburn, 2001 found the insecurity related to income and job, as well as the sentiment of being old as major motives impeding entrepreneuship for employees aged 50 to 75 .

At macroeconomic level, the local cultural, politic and economic environment in Europe may impact motivation and likeliness to start a business as stated for instance by Verheul et al. (2010) that population in post-communist European regions are rather necessity or mixed motivations driven, the authors involving "regional institutional environments". Pilkovaa et al. (2014) found that government policies concerning entrepreneurship, taxes and bureaucracy are key elements differentiating developed countries from developing countries in Europe with high, respectively low levels of senior entrepreneurship. It has been argued that general political measures regarding entrepreneurship do not prove efficiency in developing countries as they would mainly encourage the necessity entrepreneurship (Verheul and van Stel, 2007). Entrepreneurial education seems to have a positive impact on stimulation of opportunity driven entrepreneurship (Verheul et al., 2010). Also Rogoff (2008) argued the necessity of clear public communication toward seniors and education of potential senior entrepreneurs as to their possibilities to acquire or start a business. The economic situation in terms of levels of start-up rate and unemployment level among potential entrepreneurs, the so called 
'regional entrepreneurial milieu' impacts the individual propensity to become selfemployed (Wagner, 2002).

Overall it can be concluded that senior entrepreneurship is a complex field with a lot of factors to be considered. There is most probably no general valid pattern to increase entrepreneurship within aging population; country-specifics should be taken into account and a lot of factors with a continuous dynamic. As it has been argued that countries with higher levels of young or old age population present lower rates of entrepreneurial activity (Lévesque and Minniti, 2011), based on population dynamics and the above presented aspects, it can be concluded that the time to act upon increasing the entrepreneurship in senior population is now (especially for a country like Romania). This is because such measures (with the exception of e.g. financial means offered to older entrepreneurs to start a business) are usually requiring time for educating people and producing the needed shift in mentality. There are however also voices considering that investing in development of entrepreneurship in ageing population is not the best alternative (Lewis and Walker, 2011). But also these authors stated that further empirical investigation is needed, an idea which everyone would easily agree. Entrepreneurship in ageing population cannot be a scale phenomenon as not all seniors have abilities/interest/availability to become entrepreneurs. It is also true that some businesses may fail and many may be limited. But there is for sure a considerable potential in this age category that may have a valuable contribution if properly used. That is why studies should address the benefits of encouraging senior entrepreneurship, and also focus on further solutions for counteracting the effects of an ageing population.

\section{Methodology}

After analyzing the pulse of self-employment in Romania for people falling within age group 60+ years (Păunescu and Blid, 2017), this paper intends to approach some key aspects related to the entrepreneurial activity at regional level in Romania for the same age cohort.

For achieving its goals, the paper has as specific objectives to analyze which fields of activity raised the interest of senior entrepreneurs and to identify which size clusters reached the companies established by seniors in the last 5 years.

For the purpose of this paper there have been acquired from the Romanian Trade Registry two samples cumulating 200 limited liability companies. The criteria set for the samples were: companies established within last 5 years, still operating; a single shareholder aged 60+ years (when established and at present); companies entering the panel on basis of decreasing turnover starting with the highest yearly turnover as per 2016. The samples of data were: 50 companies for Bucharest-Ilfov, an area with a better development and 150 companies for South-Muntenia, a region with a lower development level. Together these regions cover $15 \%$ of the Romanian's surface and $26.8 \%$ of the total Romania's population (2011 census).

\section{Results and discussions}


Data obtained from Trade Registry were name of company, registry number, VAT code and contact details. On the Ministry of Finance website, using VAT code, one can have access to several details about each company searched for.

Identifying based on employees' number which size clusters reached the start-ups established by seniors in the last 5 years

The companies included in the panel for South-Muntenia Region were mainly set-up in 2015 and 2016. In Bucharest panel the companies are well balanced throughout the entire 5years period.

Total employees number for 2016 (yearly average) was 237 for 50 companies in Bucharest-Ilfov and 567 for 150 companies of South-Muntenia. About 87\% of the companies in total for both samples have none or max. 5 employees. That is in line with statements according to which older entrepreneurs are not significant employers (Curran and Blackburn, 2001; de Kok et al., 2010). In South-Muntenia 8 companies are employing $87 \%$ of the total employees in the rural area, and 8 enterprises are employing $69 \%$ of the total employees in urban area. In Bucharest-Ilfov 11 companies have more than 5 employees, cumulating $65 \%$ of the total employees. Excluding companies with more than 25 employees, the average employees' number per company is less than 2 in SouthMuntenia and about 4 in Bucharest-Ilfov. 4 companies with more than 25 employees have been set-up in 2012-2013, one in 2016.

Table 1. Number of start-ups and employees for 60+ age category by of year of establishment

\begin{tabular}{|c|l|r|r|r|r|r|}
\multicolumn{1}{c|}{} & Start-up year & $\mathbf{2 0 1 2}$ & $\mathbf{2 0 1 3}$ & $\mathbf{2 0 1 4}$ & $\mathbf{2 0 1 5}$ & $\mathbf{2 0 1 6}$ \\
\hline \multirow{4}{*}{$\begin{array}{c}\text { South- } \\
\text { Muntenia }\end{array}$} & No. of companies & 20 & 23 & 13 & 48 & 46 \\
\cline { 2 - 6 } & $\begin{array}{l}\text { Total employees' number } \\
(2016)\end{array}$ & 116 & 204 & 27 & 116 & 104 \\
\cline { 2 - 6 } & $\begin{array}{l}\text { Average employees' no. } \\
\text { per 2016 }\end{array}$ & 5.8 & 8.9 & 2.1 & 2.4 & 2.3 \\
\hline \multirow{4}{*}{$\begin{array}{c}\text { Bucharest- } \\
\text { Ilfov }\end{array}$} & No. of companies & 7 & 9 & 15 & 10 & 9 \\
\cline { 2 - 6 } & $\begin{array}{l}\text { Total employees' number } \\
\text { (2016) }\end{array}$ & 38 & 91 & 41 & 36 & 31 \\
\cline { 2 - 6 } & $\begin{array}{l}\text { Average employees' no. } \\
\text { per 2016 }\end{array}$ & 5.4 & 10 & 2.7 & 3.6 & 3.4 \\
\hline
\end{tabular}

Source: Processed based on data from Trade Registry / searched for on Romanian Ministry of Finance website.

Table 2. Start-ups for 60+ age category by number of employees

\begin{tabular}{|l|c|c|}
\cline { 2 - 3 } \multicolumn{1}{c|}{} & \multicolumn{2}{c|}{ No of companies } \\
\hline Employees no. & South-Muntenia & Bucharest-Ilfov \\
\hline 0 & 73 & 7 \\
\hline $1-5$ & 61 & 32 \\
\hline $5-25$ & 12 & 10 \\
\hline above 25 & 4 & 1 \\
\hline
\end{tabular}

Source: Processed based on data searched for on Romanian Ministry of Finance website (www.mfinante.ro). 
Identifying based on turnover level which size clusters reached the start-ups established by seniors in the last 5 years

A criterion for samples was decreasing turnover, the samples being limited (not considering all companies in the regions), a comprehensive analysis based on turnover is not possible. However there is to notice that out of the biggest 150 companies set-up in South-Muntenia in the last 5 years, last 41 have 0 Euro turnover in 2016 (with 21 companies set-up in 2016). The biggest company in the sample for this region has been established in 2013 and its 2016 turnover was 4.8 Mil. Euro. 50\% of the companies are having in 2016 a yearly turnover less than 10.000 Euro (33 companies founded in 2016) and only $22 \%$ have the 2016 yearly turnover above 50 kEuro.

For Bucharest-Ilfov the biggest company in the sample has also been established in 2013 and had in 2016 a turnover of 98.4 M Ron (21.9 Mil Euro). The last company in the sample had a turnover of approx. 48 kEuro. Considering this is the most developed region in the country and the sample included companies set-up in the last 5 years, this seems a pretty low level of turnover for the company ranked $50^{\text {th }}$.

Table 3. Start-ups number for $60+$ age category by level of turnover

\begin{tabular}{|l|c|c|}
\cline { 2 - 3 } \multicolumn{1}{c|}{} & \multicolumn{2}{c|}{ Number of companies } \\
turnover (Euro)* & $\begin{array}{c}\text { South- } \\
\text { Muntenia }\end{array}$ & $\begin{array}{c}\text { Bucharest- } \\
\text { Ilfov }\end{array}$ \\
\hline above 1 Mil & 2 & 2 \\
\hline $500 \mathrm{k}-1$ Mil & 5 & 4 \\
\hline $100 \mathrm{k}-500 \mathrm{k}$ & 14 & 21 \\
\hline $50 \mathrm{k}-100 \mathrm{k}$ & 12 & 19 \\
\hline $25 \mathrm{k}-50 \mathrm{k}$ & 23 & 4 \\
\hline 10k - 25k & 19 & \\
\hline under 10k & 75 & \\
\hline Total & $\mathbf{1 5 0}$ & $\mathbf{5 0}$ \\
\hline
\end{tabular}

Source: Processed based on data searched for on Romanian Ministry of Finance website *considering the average exchange rate Euro/Ron for 2016.

Identifying which fields of activity raised interest for senior entrepreneurs

In South-Muntenia 55\% of enterprises considered have been set-up in urban area. 53\% of the companies in the sample operate in trade, construction works, transport or food production. 15 businesses in the rural and 8 in the urban area were represented by small stores mainly with food and beverages.

Table 4. Number of start-ups of 60+ age category in South-Muntenia by field of activity and location

\begin{tabular}{|l|c|c|}
\cline { 2 - 3 } \multicolumn{1}{c|}{} & \multicolumn{2}{c|}{ No. of companies } \\
\hline Field of activity & Rural & Urban \\
\hline trade & 17 & 21 \\
\hline construction works & 9 & 9 \\
\hline transport services & 7 & 8 \\
\hline food production & 4 & 4 \\
\hline
\end{tabular}

DOI: 10.2478/picbe-2018-0014, pp. 139-150, ISSN 2558-9652| Proceedings of the $12^{\text {th }}$ International Conference on Business Excellence 2018 


\begin{tabular}{|l|c|c|}
\hline restaurants\&bars & & 6 \\
\hline health services & 2 & 3 \\
\hline $\begin{array}{l}\text { consulting and IT and information } \\
\text { technology services }\end{array}$ & 4 & 1 \\
\hline business consultancy & 1 & 3 \\
\hline body and beauty care services & 2 & 2 \\
\hline fabrication of non-food products & 4 & \\
\hline insurance broker & & 3 \\
\hline advertising & 2 & 1 \\
\hline $\begin{array}{l}\text { renting own or rented real } \\
\text { estate/accommodation }\end{array}$ & 2 & 1 \\
\hline $\begin{array}{l}\text { cultivation of cereals and fruit } \\
\text { trees }\end{array}$ & 3 & 3 \\
\hline installation works & 8 & 20 \\
\hline others & $\mathbf{6 8}$ & $\mathbf{8 2}$ \\
\hline Total
\end{tabular}

PICBE | 146

Source: Processed based on data searched for on Romanian Ministry of Finance website.

In Bucharest-Ilfov $50 \%$ of the companies are in trade, production of non-food articles and construction works. Both fabrication and trade of non-food articles have a bigger weight compared to South-Muntenia.

Table 5. Number of start-ups for $60+$ age category in Bucharest-Ilfov by field of activity

\begin{tabular}{|l|c|}
\hline Field of activity & $\begin{array}{c}\text { No. of } \\
\text { companies }\end{array}$ \\
\hline trade & 13 \\
\hline fabrication of non-food products & 7 \\
\hline construction works & 5 \\
\hline business \& communication consultancy & 4 \\
\hline transport services & 3 \\
\hline $\begin{array}{l}\text { IT and information technology } \\
\text { consulting/services }\end{array}$ & 2 \\
\hline others & 16 \\
\hline Total & $\mathbf{5 0}$ \\
\hline
\end{tabular}

Source: Processed based on data searched for on Romanian Ministry of Finance website.

Regrouping the fields of activity, the results of this study are different from Botham and Graves (2009) research report, who argued that older founders were more likely to create business services firms (40\%), followed by trade (under $25 \%$ ) and construction firms (less than 15\%). In our case trade was found on first place (26\%) and business services ranked second (about 23\%).

\section{Conclusion}

Population ageing is a main concern for policy makers and is growing in importance. In order to address some viable solutions, this topic should be seen in correlation with 
concepts like active and healthy ageing, senior entrepreneurship. The literature in the field of senior entrepreneurship is divers however there is still room for further and deeper researches especially on Romanian market. There is no general valid pattern to increase entrepreneurship within aging population; the country-specific should be considered and many factors with a continuous dynamic.

This paper reveals rather a limited and less significant phenomenon of

PICBE | 147 entrepreneurial activity within the 60+ age cluster in Romania for the last 5 years. More businesses have been established in the urban area, but there are many also in the rural zone. The main preferred fields of activity were trade, business services, construction works and transport. The majority (87\%) of the companies founded in the last 5 years by older entrepreneurs in our samples have none or up to max. 5 employees. $86 \%$ of the companies in the South-Muntenia and 46\% in Bucharest-Ilfov have a yearly turnover under 100 kEuro. The results of this paper will be enhanced by further analysis on the same samples, with shift of focus on motivational drivers to start-up a business and external factors encouraging this phenomenon.

The major limitations of the present research are the size and the regional level of the samples.

\section{References}

Adrien, M.-H., Kirouac, S., Sliwinski, A. (1999). Women's Entrepreneurship in Canada: All that Glitters is not Gold. Universalia Occational Paper 38, 1-13. Available at: http://www.universalia.com/sites/default/files/articles/fichiers/no38_womenentr epreneurshipincanada.pdf. Accessed on $3^{\text {rd }}$ of April 2017.

Ainsworth, S. (2015). Ageing Workers and the Employee-Employer Relationship, Springer International Publishing, 243-260.

Aisa, R., Larramona G., Pueyo F. (2015). Active ageing, preventive health and dependency: Heterogeneous workes, differential behavior. Journal of Economic Behavior\&Organization 117, 1-9.

Baucus, D., Human, S.E. (1994). Second Career Entrepreneurs: A multiple case of entrepreneurial processes and antecedent variables. Entrepreneurship Theory and Practice 19(2), 41-71.

Bergmann, H., Sternberg, R. (2007). The changing face of entrepreneurship in Germany. Small Business Economics, 28(2), 205-221.

Bierwisch A., Goluchowicz K., Som 0. (2014). Stocktaking of activities in active ageing and work environment in policy, science and industry - The German case. Technological Forecasting\&Social Change, 89, 343-357.

Blanchflower, D. G., Oswald, A., Stutzer, A. (2001). Latent entrepreneurship across nations. European Economic Review, 45(4-6), 680-691.

Bohlmann, C., Rauch, A., Zacher, H. (2017). A Lifespan Perspective on Entrepreneurship: Perceived Opportunities and Skills Explain the Negative Association between Age and Entrepreneurial Activity, Frontiers in Psychology. Available at: https://www.frontiersin.org/articles/10.3389/fpsyg.2017.02015/full. (Accessed on $20^{\text {th }}$ of Dec 2017).

Botham, R., Graves, A. (2009). The grey economy. How third age entrepreneurs are contributing to growth. Nesta Research Report. Available at: 
https://www.nesta.org.uk/sites/default/files/the_grey_economy.pdf (accessed Jun 2016).

Buttner, E.H., Moore, D.P. (1997). Women's Organizational Exodus to Entrepreneurship: Self-reported Motivations and Correlates with Success. Journal of Small Business Management, 35(1), 34-46.

Curran, J., Blackburn, R. (2001). Older people and the enterprise society: Age and selfemployment propensities. Work, Employment and Society, 15(4), 889-902.

Emile, M., Chalabaev, A., Stephan Y., Corrion K., D’Arripe-Longueville F. (2014). Aging stereotypes and active lifestyle: Personal correlates of stereotype internalization and relationships with level of physical activity among older adults. Psychology of Sport and Exercise 15, 198-204.

European Commission, The 2015 Ageing Report: Economic and budgetary projections for the 28 EU Member States (2013-2060), EUROPEAN ECONOMY 3|2015. Available at: http://ec.europa.eu/economy_finance/publications/european_economy/2015/pdf/ ee3_en.pdf (Accessed $8^{\text {th }}$ of Jan. 2016).

European Commission, EIP on AHA, What is the European Innovation Partnership on Active and Healthy Ageing (EIP on AHA)? Available at:

https://ec.europa.eu/eip/ageing/about-the-partnership_en (Accessed on $3^{\text {rd }}$ of April 2017).

European Commission. Eurostat statistics on Population structure and ageing. Available at: http://ec.europa.eu/eurostat/statisticsexplained/index.php/Population_structure_and_ageing. Accessed on $3^{\text {rd }}$ of April 2017).

Fairlie R. W., Fossen F.M., Opportunity versus Necessity Entrepreneurship: Two Components of Business Creation, SIEPR Discussion Paper No. 17-014, Available at https://siepr.stanford.edu/sites/default/files/publications/17-014.pdf ; accessed $1^{\text {st }}$ of Dec. 2017

Foy C.G., Vitolins M.Z., Case L.D., Harris S.J, Massa-Fanale C., Hopley R.J., Gardner L., Rudiger N., Yamamoto K., Swain B., Goff D.C. Jr., Darnhauer S.C., Booth D., Gaspari J. (2013), Incorporating prosocial behavior to promote physical activity in older adults: Rationale and Design of the Program for Active Ageing and Community Engagement (PACE). Contemporary Clinical Trials 36, 284-297.

Giacomin, O., Guyot, J.L., Janssen, F., Lohest, O. (2007). Novice Creators: Personal Identify and Push Pull Dynamics. Crecis, Working paper 7/10. Available on https://cdn.uclouvain.be/public/Exports\%20reddot/iag/documents/WP_0710_Franssen.pdf Accessed 1 st of Nov 2017

Harms, R., Luck, F., Kraus, S. , Walsh, S. (2014). On the motivational drivers of gray entrepreneurship: An exploratory study. Technological Forecasting \& Social Change $89,358-365$.

Huges, K.D. (2003). Pushed or pulled? Women's entry into self-employment and small business ownership. Gender, Work and Organization, 10 (4), 433-454.

Kalache, A., Kickbush, I. (1997). A global strategy for healthy ageing. World Health, 4, 4-5.

Kautonen, T. (2008). Understanding the older entrepreneur: comparing third age and prime age entrepreneurs in Finland. International Journal of Business Science and Applied Management, 3(3), 3-13

Kautonen, T., S. Down and L. South (2008). Enterprise support for older entrepreneurs: The case of PRIME in the UK. International Journal of Entrepreneurial Behaviour \& Research, 14, 85-101. 
Kautonen, T., Down, S., Minniti, M. (2014). Ageing and entrepreneurial preferences. Small Business Economics, 42(3), 579-594.

Kean, R. C, Van Zandt, S. and Maupin, W. (1993). Successful Ageing: The Older Entrepreneur, Journal od Women and Aging, 5(1): 25-42.

Kok, J. de, Ichou A., Verheul, I. (2010), New Firm Performance: Does the Age of Founders Affect Employment Creation? Scales Research Reports H201015, EIM Business and Policy Research. Available at: https://core.ac.uk/download/pdf/6445736.pdf (Accessed on 12 January, 2017).

Kraus S., Bouncken, R. B. (2014), Senior entrepreneurship: definitions and underlying theories, International Journal of Business Research, IJBR, 14(3), 209-215.

Lassen, A.J., Bønnelycke J., Otto L. (2015). Innovating for ,active ageing' in a public-private innovation partnership: Creating doable problems and alignment. Technological Forecasting \& Social Change, 93, 10-18.

Lassen, A.J,. Moreira, T. (2014). Unmaking old age: Political and cognitive formats of active ageing. Journal of Ageing Studies, 30, 33-46.

Lévesque, M., Minniti, M. (2006). The effect of aging on entrepreneurial behavior. Journal of Business Venturing, 21(2), 177-194.

Lévesque, M., Minniti, M. (2011). Age matters: How demographics influence aggregate entrepreneurship. Strategic Entrepreneurship Journal, 5(3), 269-284.

Levy, B.R., Myers, L.M. (2004). Preventive health behaviors influenced by self-perceptions of aging. Preventive Medicine, 39, 625-629.

Lewis, K., \& Walker, E. A. (2011). Self-employment: Policy panacea for an ageing population? Small Enterprise Research, 18(2), 143-151.

Maâlaoui, A., Castellano, S., Safraou, I., Bourguiba, M. (2013). An exploratory study of seniorpreneurs. A new model of entrepreneurial intentions in the French context. International journal of entrepreneurship and small business, 20 (2), 148-164.

Moulaert, T., Paris, M. (2013). Social policy on ageing: The case of "active ageing" as a theatrical methaphor. International Journal of Social Science Studies, 1(2), 113-123.

Parker, S.C. (2009). The economics of self-employment and entrepreneurship, Cambridge University Press, Cambridge, 113-160.

Păunescu C, Blid L., 2017. Seniorpreneur as a career option for smart active ageing. A study on Romania, Proceedings of the International Conference on Business Excellence, $11,(1)$.

Pilkovaa A., Holienkaa M., Rehaka J. (2014). Senior entrepreneurship in the perspective of European entrepreneurial environment. Procedia Economics and Finance, 12, 523 532.

Robichaud Y., LeBrasseur R., Nagarajan K.V. (2010). Necessity and Opportunity-driven Entrepreneurs in Canada: An Investigation into their Characteristics and an Appraisal of the Role of Gender, Journal of Applied Business \& Economics, 11 (1), 59.

Rogoff E.G. (2008), The Issues and Opportunities of Entrepreneurship After Age 50, Occasional Papers, AARP Office of Academic Affairs. Available on https://assets.aarp.org/www.aarp.org_/articles/research/Entrepreneurship.pdf. (Accessed 20th of Jul. 2017).

Romanian National Statistics Institute. The stable resident population. Demografic structure. Population on census of [...] 2011 - counties and categories of localities, Available at: http://www.recensamantromania.ro/noutati/volumul/ (Accessed 1st of Nov. 2017). 
Singh, G., DeNoble, A. (2003). Early retirees as the next generation of entrepreneurs. Entrepreneurship Theory \& Practice, 23, 207-226.

Staudinger, U. M. (1999). Older and Wiser? Integrating Results on the Relationship Between Age and Wisdom-related Performance. International Journal of Behavioral

Development, 23(3), 641-664.

Thorgren, S., Sirén, C., Nordström, C., Wincent, J. (2016). Hybrid entrepreneurs' second-step choise: The nonlinear relationship between age and intention to enter full-time entrepreneurship. Journal of Business Venturing Insights, 5, 14-18.

United Nations, World population prospects, Key findings and advanced tables, 2015

Revision, Available at:

https://esa.un.org/unpd/wpp/publications/files/key_findings_wpp_2015.pdf (Accessed 20th of Jul. 2017).

Verheul, I., Thurik, R, Hessels, J., van der Zwan, P. (2010). Factors Influencing the Entrepreneurial Engagement of Opportunity and Necessity Entrepreneurs, SCALE Scientific analysis of Entrepreneurship and SMEs, available at: http://ondernemerschap.panteia.nl/pdf-ez/h201011.pdf, (Accessed on $1^{\text {st }}$ of Nov. 2017).

Verheul, I., van Stel, A. (2007). Entrepreneurial diversity and economic growth. SCALE Scientific analysis of entrepreneurship and SMEs, 1-29. Available on http://citeseerx.ist.psu.edu/viewdoc/download;jsessionid=A82F4969300A91D83E5 D9ADBD0744C88?doi=10.1.1.625.7998\&rep=rep1\&type=pdf; accessed on $1^{\text {st }}$ of Oct. 2017.

Wagner, J. (2002). The Impact of Risk Aversion, Role Models, and the Regional Milieu on the Transition from Unemployment to Self-Employment: Empirical Evidence for Germany. Discussion Paper . Institute for the Study of Labor, Discussion Paper No. 468. Available at:

http://citeseerx.ist.psu.edu/viewdoc/download?doi=10.1.1.494.7223\&rep=rep1\&typ $\mathrm{e}=$ pdf. (Accessed on 20th of Jul. 2017).

Walker, E..A., Webster, B.J., (2007). Gender, age and self-employment: some things change, some stay the same. Women in Management Review, 22, 122-135.

Walker, A. (2009). Commentary: The emergence and application of active aging in Europe. Journal of Aging \& Social Policy, 21(1), 75-93.

Weber, P. and Schaper, M. (2004). Understanding the grey entrepreneur. Journal of Enterprising Culture, 12(2), 147-164.

World Health Organization (WHO) (2002). Active Ageing , A Policy Framework, Accessed on http://apps.who.int/iris/bitstream/10665/67215/1/WHO_NMH_NPH_02.8.pdf on $1^{\text {st }}$ of Nov., 2017.

Zhang, T. (2008). Elderly Entrepreneurship In An Aging Us Economy: It's Never Too Late. Vol. 2 of Series on economic development and growth. World Scientific, 5-8. 